\title{
Solar Dryers for Tropical Food Preservation: Thermophysics of Crops, Systems and Components
}

\author{
Vivek Tomar \\ Indian Institute of Technology Delhi \\ G. N. Tiwari \\ Indian Institute of Technology Delhi \\ Brian Norton \\ Technological University Dublin, brian.norton@tudublin.ie
}

Follow this and additional works at: https://arrow.tudublin.ie/dubenart

Part of the Other Engineering Commons

\section{Recommended Citation}

Tomar, V, Tiwari, G. \& Norton, B. (2017). Solar dryers for tropical food preservation: thermophysics of crops, systems and components. Solar Energy, 154, pp.2-13. doi:10.1016/j.solener.2017.05.066

This Article is brought to you for free and open access by the Dublin Energy Lab at ARROW@TU Dublin. It has been accepted for inclusion in Articles by an authorized administrator of ARROW@TU Dublin. For more information, please contact arrow.admin@tudublin.ie, aisling.coyne@tudublin.ie,gerard.connolly@tudublin.ie.

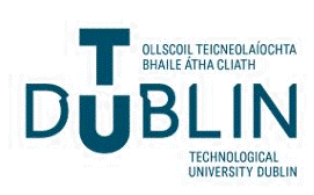




\title{
Solar dryers for tropical food preservation: Thermophysics of crops, systems and components
}

\author{
Vivek Tomar ${ }^{\mathrm{a}}$, G.N. Tiwari ${ }^{\mathrm{a}}$, Brian Norton ${ }^{\mathrm{b}, *}$ \\ ${ }^{a}$ Centre for Energy Studies, Indian Institute of Technology Delhi, New Delhi 110016, India \\ ${ }^{\mathrm{b}}$ Dublin Energy Lab, Dublin Institute of Technology, Dublin 7, Ireland
}

\section{A R T I C L E I N F O}

\section{Article history:}

Received 20 October 2016

Received in revised form 4 April 2017

Accepted 20 May 2017

Available online $\mathrm{xxxx}$

\section{Keywords:}

Drying

Solar dryer

Moisture content

Drying rates

Thin-layer drying

Crop properties

Psychrometrics

Air heating solar collector

\begin{abstract}
A B S T R A C T
Drying reduces the moisture content of harvested crops thus slowing decay processes to enable longerterm storage. Solar dryers contain the crop being dried, to enhance solar energy collection incurring lower crop losses than are associated with open-sun drying and recurrent costs than are inherent to uses of fossil-fuels for drying. The influences of key environmental, operational and design parameters for solar dryers are discussed including: (i) psychrometry of drying processes and ambient conditions, (ii) how initial crop properties are converted to final desired product attributes, (iii) feasibility of using powered components such as fans and (iv) air-heating solar collector selection.
\end{abstract}

(c) 2017 Elsevier Ltd. All rights reserved.

\section{Introduction}

Solar crop drying ensues naturally when seeds dry in-situ to render them sufficiently light for air-borne dispersal. Human intervention to dry crops in the open sun to enable their storage for offseason food consumption was probably intrinsic to the inception of farming-based civilizations. The key strategic goal in preserving crops is to reduce the number of undernourished people worldwide (Anon., 2004). Fiber and energy is provided by carbohydrates and protein usually retained after a drying process.

Open sun drying simply exposes harvested crops to solar radiation by placing them on the ground or a mat. It is prone to high crop losses due to (i) uneven moisture removal, (ii) insects and rodents consuming the crop and (iii) failure to achieve safe storage moisture content before the crop has to be collected. As an example, the estimated annual postharvest losses of various commodities together with the associated costs for India is shown in Table 1.

The first modern use of fossil fuels in drying was recorded in France in 1795 for drying of thinly sliced fruits and vegetables (Delong, 1992). Fossil-fuelled dryers are now commonplace as they can operate in any ambient conditions, are readily controlled and their operation and maintenance infrastructures are well estab-

\footnotetext{
* Corresponding author.

E-mail address: brian.norton@dit.ie (B. Norton).
}

lished. However, in many remote rural locations supplies of fossil fuels can be (i) insecure (ii) expensive and require combustion equipment and (iii) their use incurs emissions of both local pollution and global greenhouse gases (Imre, 1993). In contrast, solar drying often constitutes a cost-effective and environmentally sustainable use of local solar energy resources and fabrication labour resources.

Solar dryers can be distinguished from open-sun drying by (i) enclosure of the drying crop and (ii) direct or indirect production of a solar heated airflow. When compared with open-air sun drying, solar drying generally is (i) faster, (ii) more efficient (iii) hygienic and (iv) incurs lower crop losses (Arata et al., 1993; Budin and Mihelic-Bogdanic, 1994; Chua and Chou, 2003; Karim and Hawlader, 2004; Mahapatra and Imre, 1990; Muhlbauer, 1986; Zaman and Bala, 1989). There are generally more viable than open sun drying as they provide more control and protection of product quality over a wider range of weather conditions (Alam and Singh, 2004; Sodha and Chandra, 1994; Lorriman and Hollick, 2003; Nair and Bongirwar, 1994; Tiwari, 2003; Esper and Muhlbauer, 1998; Farkas, 2003). In a solar dryer, solar radiation passes through a transparent aperture and retained as heat in a drying chamber, a solar collector, or both. In a passive solar dryer, thermal energy transferred from solar energy collection to the drying chamber is by natural convection whereas in an active system a fan drives heated air through the dryer (Norton, 2013). The interrelationship 
Table 1

Estimates of post-harvest losses for various commodities in India (Alam et al., 1980; Anon, 2004).

\begin{tabular}{llll}
\hline & & \multicolumn{2}{l}{ Post-harvest losses } \\
\cline { 3 - 4 } & & \% of produce & Value (Rupees in Crore) \\
\hline Commodity & Grains & 10 & 16,500 \\
& Pulses & 15 & 2000 \\
& Fruits & 30 & 13,600 \\
& Vegetables & 30 & 14,100 \\
& Floriculture & 40 & 400 \\
& Fish & 15 & 2700 \\
& Dairy (milk) & 1 & 900
\end{tabular}

Total Rs. 50,200 Crore

between the key factors that determine solar dryer viability (Ekechukwu and Norton, 1999b) are summarised in Fig. 1.

\section{Psychometry of air in a solar dryer}

The more dry the surrounding air, the greater the rate of evaporation from a crop that lowers the wet bulb temperature. The specific humidity of unsaturated air increases due to water evaporation from a crop as energy transferred from air to water. A thermal equilibrium prevails when the energy transferred from warm air to the crop becomes equal to energy needed for water vaporization. At temperatures below this equilibrium thermodynamic wet bulb temperature or adiabatic saturation temperature, air will rapidly become saturated and if cooled further, will lose water in the form of dew above $0{ }^{\circ} \mathrm{C}$. Water vapour moves from air with a higher humidity ratio (i.e. ratio of water vapour weight to dry air weight) to air with a lower humidity ratio.

As indicated in Fig. 2 for appropriate combination of humidities and temperatures, air taken directly into a drying chamber will be heated sufficiently to enable drying. When the temperature and humidity of directly-introduced ambient air would provide an insufficient drying rate, an air heating solar energy collector produces higher temperature air for introduction to the drying chamber. The indicative conditions for which use of air heating collector is advised are illustratively in Fig. 2; The specific for a particular installation are contingent conditions would depend on crop parameters, collector characteristics and drying chamber specifications (Ekechukwu and Norton, 1999a).
Wet-basis moisture content (defined as the relative weights of moisture present per unit of undried material) is used generally for commercial purposes. For system engineering purposes, the (closely related; see Fig. 3) dry basis moisture content (defined as the weight of moisture present per unit weight of totally dry material) is preferred as on a dry basis the same weight changes are associated with each percentage moisture reduction (Ekechukwu and Norton, 1999a, 1999b; Ekechukwu, 1999). The final moisture contents required for long-term storage of crops, are referred as safe storage moisture content are listed for common crops in Table 2.

National and international standards specify labelling for correct ingredient and nutritional information to ensure that products are safe and fit for consumption. Nutrition colour, flavour and texture of the dried product must also be of acceptable quality to consumers. The term "quality" has three overlapping connotations; (i) degree of excellence, (ii) fitness for purpose, and/or (iii) conformance to specified requirements. The consequences of improper drying can include (i) loss of nutrients, (ii) microbial spoilage, (iii) possibility of food poisoning, (iv) lower market value and (v) excessive shrinkage.

Shrinkage during drying alters shape, reduces volume and increase surface hardness. This is a desired outcome for some crops such as some dried fruits. Non-uniform shrinkage leads to imbalanced stresses that crack surfaces. Shrinkage can limits the ability to rehydrate a dried product as moisture-absorbing capillaries are closed; for example when cauliflower is dried. (Jain and Tiwari, 2004b). The stresses causing shrinkage depend on removed water volume, internal crop structure, drying rate, temperature, relative humidity, and velocity of drying air. Being a major factor when controlling the drying rate (Rahman et al., 1996; Zogzas et al., 1994), shrinkage has been the subject of extensively modelling; (Lozano et al., 1983, 1980; Mayor and Sereno, 2004; Mclaughlin and Magee, 1998; Mulet et al., 2000; Ochoa et al., 2002; Park, 1998; Rahman et al., 1996; Ratti, 1994; Simal et al., 1998; Wang and Brennan, 1995). To avoid high drying temperatures can adversely affect the colour and phenolic composition of aromatic, herbal and medicinal plants. pre-treatments have been devised for specific herbs such as thyme (Lahnine et al., 2016). For colour retention in dried cherry tomatoes, osmotic dehydration in a hypertonic solution has been employed for partial water removal before subsequent drying in a solar dryer (Nabneun et al., 2016) to produce high quality dried tomatoes with desired colour in a

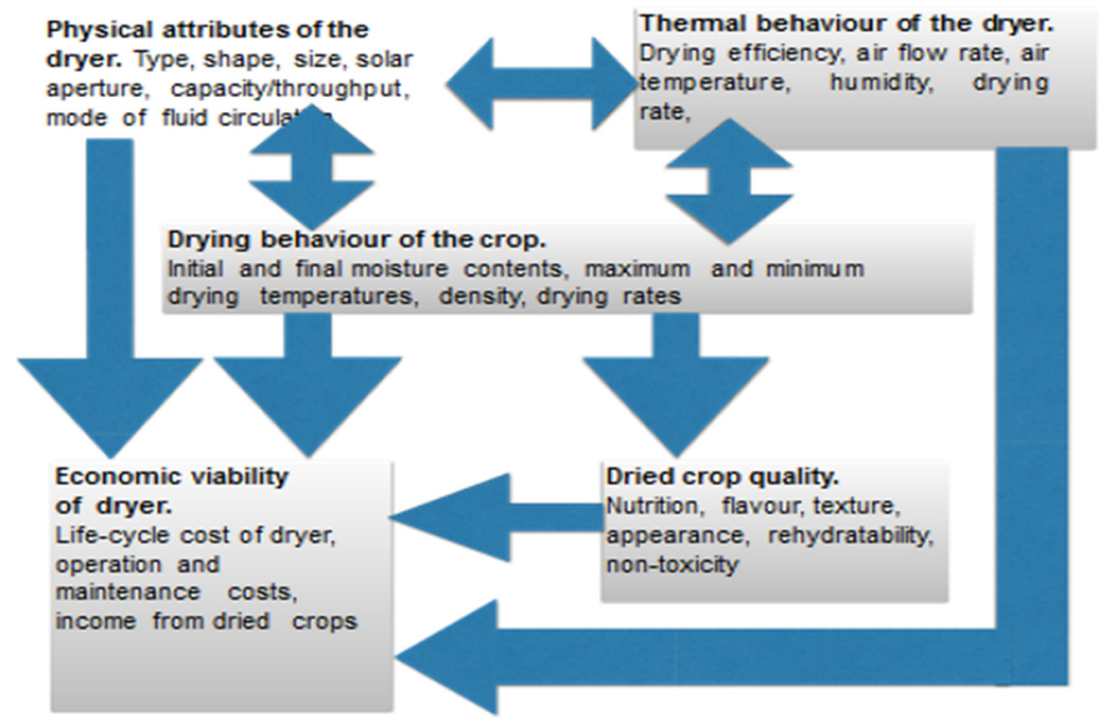

Fig. 1. Interplay between key grouped aspects of solar dryer viability. 


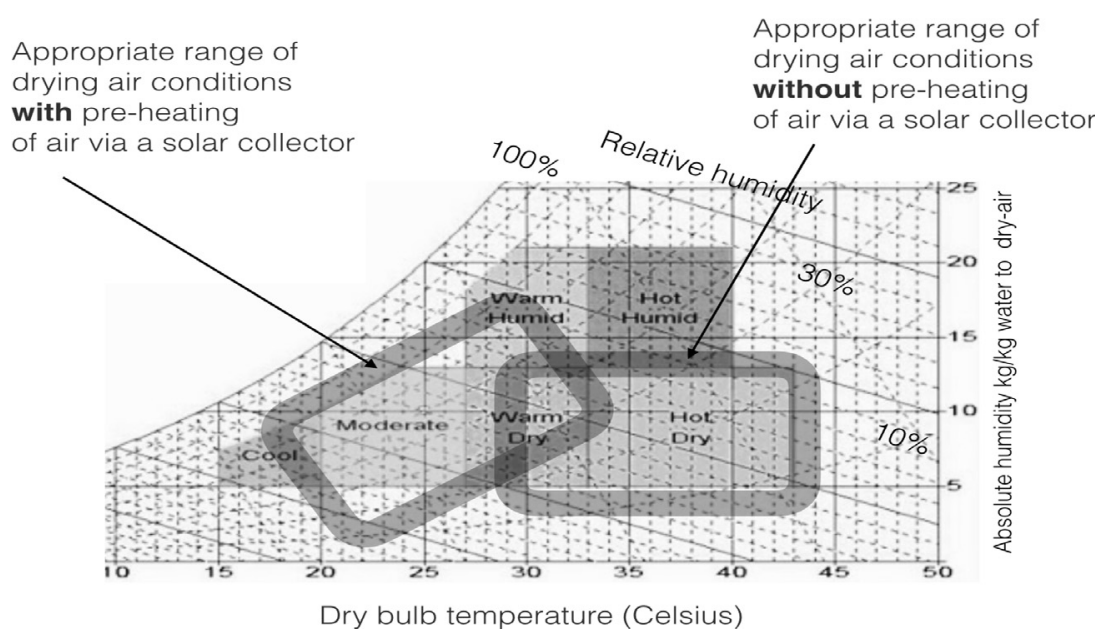

Fig. 2. Indicative psychometry of conditions for the inclusion in a solar dryer of an air heating solar collector.

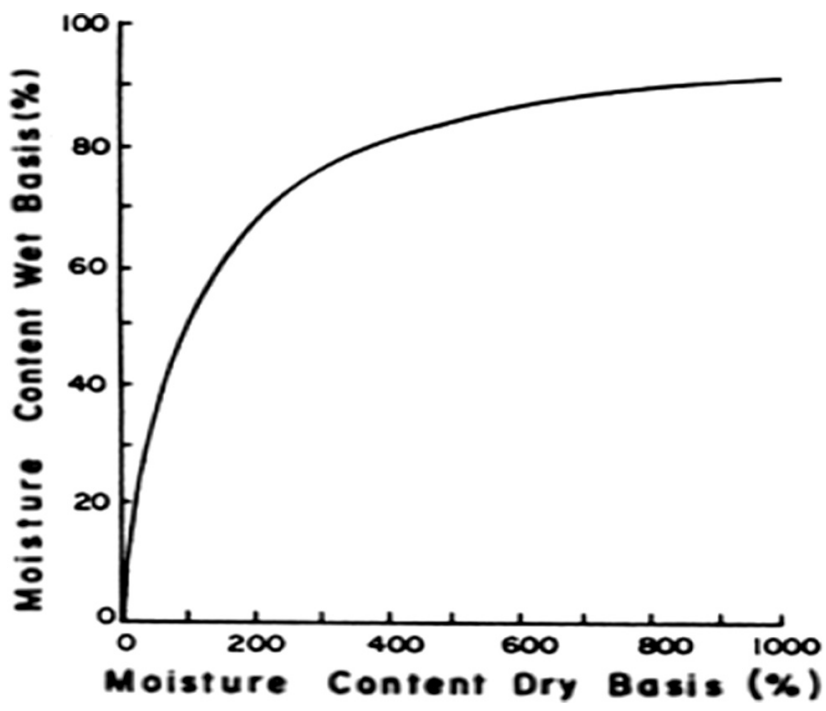

Fig. 3. Difference between moisture contents measured on wet and dry basis.

considerably reduced drying time. The latent heat of vapourisation depends on the crop, its preparation, moisture content, and temperature (Ekechukwu and Norton, 1999a; Ekechukwu, 1999).

Each crop has a characteristic water vapour pressure below or above which moisture will be absorbed or desorbed moisture respectively for particular combinations of temperature and moisture content, At equilibrium moisture content, the corresponding relative humidity of the immediate surrounding air is also in equilibrium with its environment. For particular temperature and relative humidity, a particular crop's equilibrium moisture content depends on the specific crop variety, maturity at harvest, and growth history (Soysal and Öztekin, 2001) Two methods are used to determine equilibrium moisture content (i) in the static method, a crop is exposed to still surrounding air without agitation; however, to reach equilibrium long exposure of the crop, can allow mould to grow before equilibrium is reached and (ii) in the dynamic method, the air temperature in an the crop enclosure is controlled thermostatically and the relative humidity of the surrounding air is regulated with either an acid or a saturated salt solution. Static equilibrium moisture contents determination is preferred for examining stored crops whereas dynamic methods used for crop samples taken from dryers in operation (Bala, 2003). Several theoretical, semi-theoretical and empirical models for the moisture equilibrium isotherms of agricultural crops produces have proposed to determine the relationship between equilibrium moisture content and equilibrium relative humidity (Brunauer et al., 1938; Day and Nelson, 1965; Henderson, 1952; Thomson et al., 1968; Chen and Clayton, 1971; Pfost et al., 1976; Iglesias et al., 1976; Chen and Morey, 1989; Soysal and Öztekin, 2001; Blanco-Cano et al., 2016a). There is no universal equation that represents accurately the moisture equilibrium isotherms of all agricultural crop products. Illustrative representative examples of the relationships between equilibrium moisture content for selected crops are given in Fig. 4.

\section{Drying processes}

Bound moisture, which exerts an equilibrium vapour pressure less than pure water at the same temperature, is moisture trapped in closed capillaries and/or the water component of juices held within a material by the surface tension. Agricultural crops are generally hygroscopic materials containing both bound and unbound moisture in contrast to non-hygroscopic materials that contain only unbound water. Water vapour pressure increases when a product is heated at constant moisture content, with moisture transfer ensuing from the product to an environment at a lower vapour pressure. In drying, heat transferred to the product surface causes surface moisture evaporation. Water from inside the crop migrates to the crop's surface to replenish surface moisture lost by evaporation. Warm drying air initially rapidly removes surplus surface moisture until there a subsequent, generally slower, steady-state, drying rate prevails that diffusion processes depends on the rate that continue to move moisture to the surface by (Sodha et al., 1985).

For agricultural crops an initial heating period is followed first by an initial constant rate drying period, and then by a subsequent falling rate drying period as shown in Fig. 5. Non-hygroscopic materials, only exhibit a constant drying rate. During a constant drying rate period, the product surface become saturated with moisture at a nearly constant temperature that almost equals to the wet bulb temperature. For a particular moisture content, a constant drying rate changes to a falling drying rate when the rate of moisture transfer through diffusion from within the product to its surface become insufficient to replenish the moisture being evaporated from its surface. During the falling-rate drying period, the moisture the rate of moisture transfer through diffusion from within the product to its surface remains less than the moisture being evaporated from its surface. 
Table 2

Initial and final moisture contents and maximum allowable drying temperatures (Brooker et al., 1974; Brenndorfer et al., 1985; Sharma et al., 1993; Brennan, 1994; Bala, 2003).

\begin{tabular}{|c|c|c|c|c|c|}
\hline & & & \multicolumn{2}{|l|}{ Moisture Content } & \multirow[t]{2}{*}{ Maximum Allowable temperature $\left({ }^{\circ} \mathrm{C}\right)$} \\
\hline & & & Initial (\% wet basis) & Final (\% wet basis)safe storage) & \\
\hline \multirow[t]{19}{*}{ Crop } & \multirow[t]{6}{*}{ Grains } & Paddy, raw & $22-24$ & 11 & 50 \\
\hline & & Paddy, & $30-35$ & 13 & 50 \\
\hline & & Maize & 20 & 16 & 45 \\
\hline & & Wheat & 24 & 14 & 50 \\
\hline & & Corn & 24 & 11 & 50 \\
\hline & & Rice & $20-22$ & $9-10$ & $40-60$ \\
\hline & \multirow[t]{7}{*}{ Vegetables } & Green peas & 80 & 6 & 65 \\
\hline & & Cauliflower & 70 & 5 & 65 \\
\hline & & Carrots & 70 & 5 & 75 \\
\hline & & Green beans & 80 & 4 & 75 \\
\hline & & Onion & 80 & 4 & 55 \\
\hline & & Garlic & 80 & 4 & 55 \\
\hline & & Cabbage & 75 & 7 & 55 \\
\hline & \multirow{6}{*}{ Fruit } & Grapes & 80 & 15 & 70 \\
\hline & & Bananas & 80 & 7 & 65 \\
\hline & & Guavas & 80 & 20 & 65 \\
\hline & & Okra & 80 & 10 & 65 \\
\hline & & Pineapple & 96 & 10 & 60 \\
\hline & & Tomatoes & 95 & 6 & 60 \\
\hline
\end{tabular}

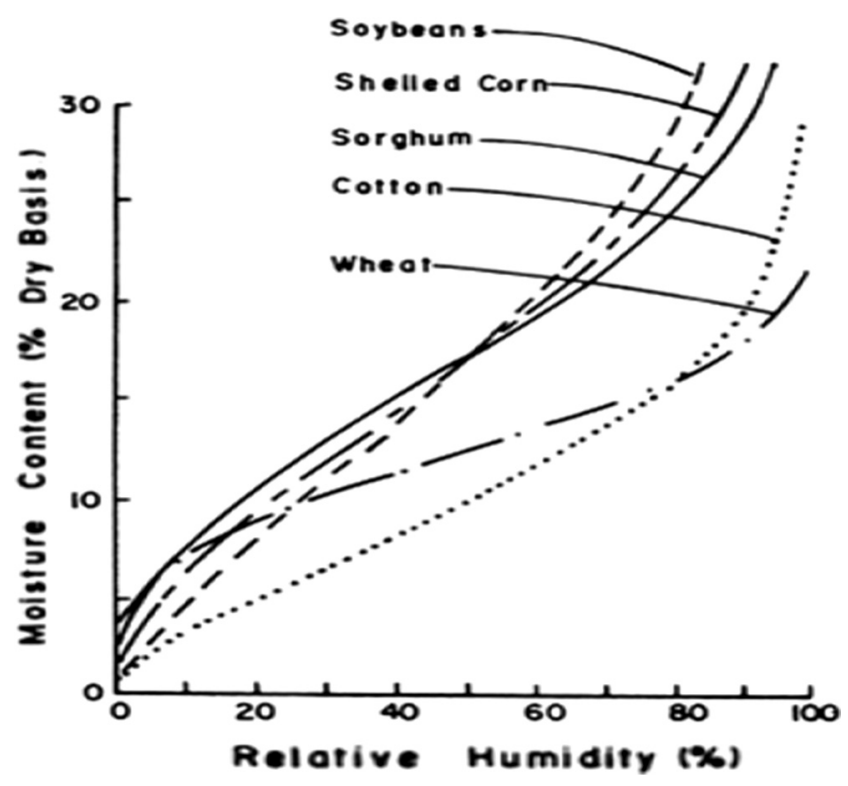

Fig. 4. Variation of equilibrium moisture content with relative humidity for different crops (Henderson, 1952).

For grains, their initial moisture content is lower than the critical moisture content, so drying takes place wholly under at a falling drying rate. The drying of fruits, most vegetables and most tropical tuber crops proceeds through both constant and falling drying rates. For thin layer drying, the large air to crop volume ratio exposes a crop to almost constant drying air conditions in which the drying rate depends mainly on crop type and size, for a given moisture content and drying air temperature (Diamante and Munro, 1991, 1993; Gunhan et al., 2005; Midilli and Kucuk, 2003; Togrul and Pehlivan, 2002; Yaldız and Ertekin, 2001; Doymaz, 2007). Even though air contains only between 0.4 and $1.5 \%$ by-weight, water vapour, effective control of the moisture

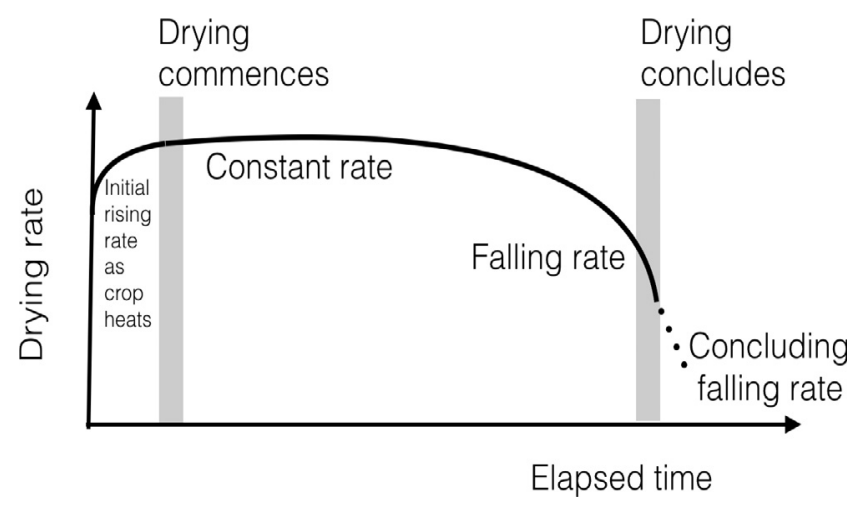

Fig. 5. Drying progression.

content of incoming air is essential for optimal heat and mass transfer in a solar dryer.

Models of moisture diffusion for porous capillary products (Luikov, 1996) have found limited application due to the lack of measured phenomenological coefficients coupling the joint effects of moisture, temperature and total pressure gradients on moisture, total mass and energy transfers in crops (Karathanos, 1999).

In deep layer drying, moisture movement takes place at a drying zone initially at the base of bed which extends up through the crop bed in the direction of the drying air as drying proceeds. This zone maintains a moisture equilibrium between the total crop mass and the drying air. Above the established drying zone, as drying has yet to commence, the crop is still at the initial moisture content, with surrounding air still in equilibrium with the initial crop moisture content. Condensation at the upper layers of the crop mass at this initial stage of drying is usually negligible. As soon as the drying front reaches the top of the bed, the falling drying rate period commences (Ekechukwu, 1999; Hall, 1980). For shallow crop bed drying at high air flow rates, to avoid overdrying the lowest layers, the drying zone can be extend up to the 
bed with the desired final average moisture content reached before equilibrium between bottom layer and the drying air is reached. The desired moisture content of the crop can be obtained by maintaining optimal air temperatures and flow rates. Guidelines for product management in small-scale solar drying are available (Flores, 2007).

Through a small portion of vitamin C may be lost by preparatory blanching, without blanching still active food enzymes can still active, reduce product quality. Blanching is essential for almost all kind of vegetables except onions, peppers, okra, herbs, and some types of corn that become sweeter as they mature. Syrup blanching before dehydration, helps to retain some vitamin content, fixes the colour, and relaxes surface tissues to aid both dehydration and rehydration. In syrup blanching, a prepared crop is submerged in a boiled syrup for about ten minutes then rinsed in cool water. Syrup blanching is use for sweeter dessert fruits like, plums, peaches, berries, nectarines, apples, pears, peaches, and apricots (Flores, 2007). Fruits such as cherries, seedless grapes, melons, prunes, plums and grapes do not require pre-treatment before drying. Light-coloured fruits such as apples, apricots, peaches, pears and nectarines become darker with loss of flavour and vitamins $A$ and $C$ during drying and storage due to oxidation (Kamiloglu et al., 2016). Direct solar exposure during drying produces dried mushrooms with a high vitamin D content (Nolle et al., in press).

\section{Solar air heaters}

\subsection{Attributes of solar air heaters}

A solar air heater can be of a wide range of types and configurations as shown in Fig. 6 (Selcuk, 1977; Ekechukwu and Norton, 1999b; Norton, 2013; Duffie and Beckman, 2013).

Absorber plates can be made of copper, aluminium and steel in decreasing order of cost and thermal conductance. Glazing is usually plastic films or glass sheets (Tiwari, 2003). To improve collection efficiency, a spectrally selective absorber coating can be used if cost effective and heat transfer between the absorber plate and the flowing air can be improved by introducing turbulence, but this also introduces additional pressure drop. In a non-porous air heater, airflow can be above and/or behind the absorber plate (Sodha et al., 1982) but most commonly air passes below the absorber in a plenum between the absorber and the insulation. Porous absorbers include slit (Li et al., 2014) and expanded-metal plates, overlapped glass plate absorbers, wire mesh and porous beds. In solar air heater with a porous absorber, solar radiation penetrates to a greater depth, radiative losses are lower and the pressure drop is usually lower than a non-porous absorber but increases with increasing dimensionless porous layer thickness (Bovand et al., 2016). However, improper selection of matrix porosity and thickness may give reduced efficiency as outside its optimum thickness a matrix may not be heated sufficiently to transfer the heat to an air stream. In non-porous solar air heaters, the air to be heated can flow above and/or below, the absorber. When both the front and rear are exposed to reflected solar energy then a double exposure air heater is formed in which the air stream receives heat from both sides of the absorber plate. In two-pass solar air heaters, air flows between either (i) two aperture or (ii) between inner cover and the absorber plate and then through the passage behind the plate (Satcunanathan and Deonarine, 1973; Caouris et al., 1978; Wijeysundera et al., 1982; a two pass mode increases collector efficiency by about 10-15\% (Pirasteh et al., 2014).

Solar air heating collectors with staggered fins attached to the rear side of the absorber plate have collector efficiencies higher than solar air heaters without fins (Fudholi et al., 2015; Mahapatra and Imre, 1990). A vee-corrugated absorber provides a large surface area for heat transfer to the air stream, through the acceptance angle for the Vee-groove must be either optimised to avoid a large amount of radiation being lost due to multiple reflections (Hollands, 1963, and/or mitigated by the use of a spectrally selective absorber coating. With this type of absorber, airflow can be either on one or both sides of the absorber (Parker, 1981). Vee-grooves can be in the form of triangular ducts made of a conductive material (e.g. aluminium) so that heat conduction gives warm walls through which air flows. Carbon steel, stainless steel, bronze and aluminium metal wood have been used to fabricate low cost porous absorber collectors (Rashidi et al., 2017). Carbon steel, is however susceptible to rust. Metal wools generally can filter and clog with dust. Overlapped glass plate air heaters consist of a set of glass plates above one another with a portion of a glass plate, beneath the preceding one being blackened with the rest transparent. Absorbed solar radiation heats the black portions of glass plate, passing heat to the air flowing parallel to these plates there by combining low-pressure drop and high efficiency at moderate operating temperatures (Löf, 1962). However, the large glass area required can lead to a high initial cost. A model has developed for optimising inflatable solar collectors to provide heated air to solar dryers (Nunes del Oliveira et al., in press). In an unglazed

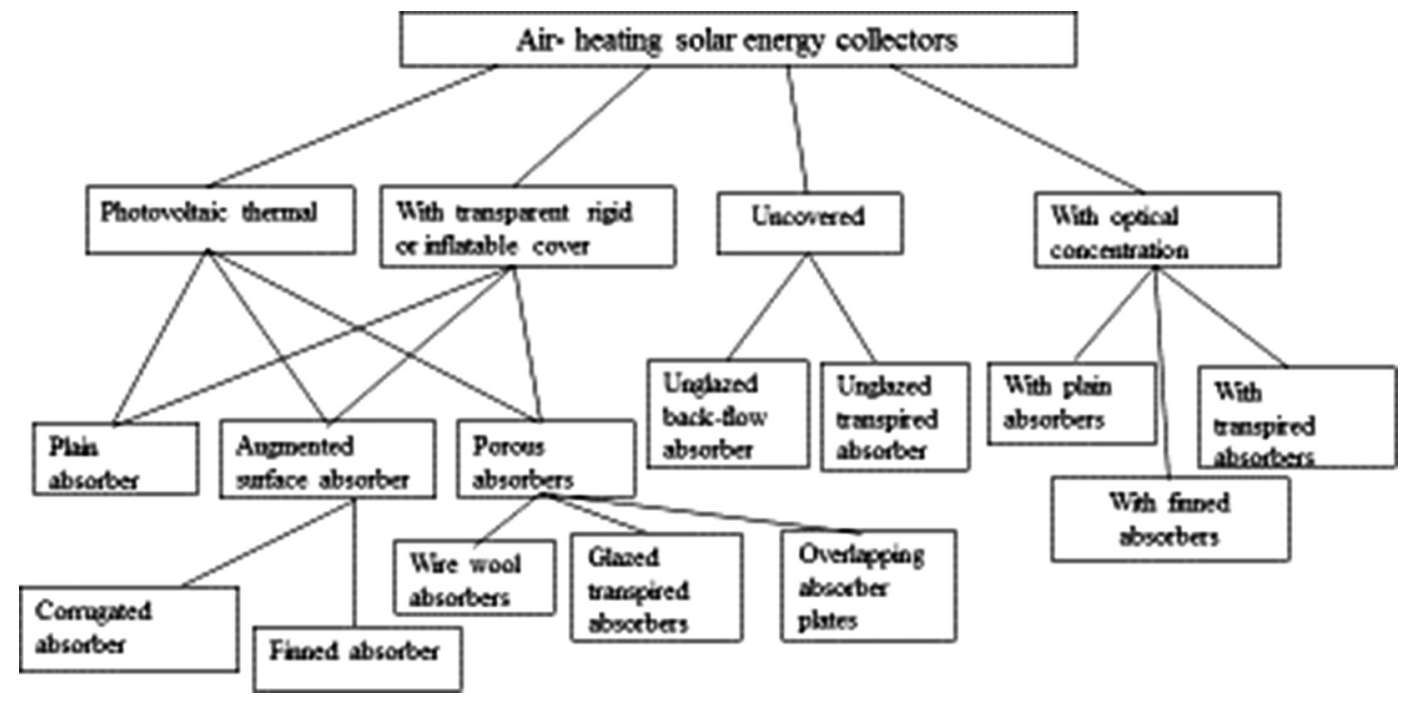

Fig. 6. Taxonomy of air heating solar energy collectors used for solar drying. 
transpired air collector a fan entrains ambient air through a perforated steel or aluminium perforated absorber surface integrated on a building façade (Shukla et al., 2012; Hollick, 1994, 1998; Lorriman and Hollick, 2003). An air channel plenum is formed between the perforated absorber and an existing wall. Generally, $100-300 \mathrm{~mm}$ diameter perforations cover $0.5-2 \%$ of the collector aperture area. $62 \%$ of heat gain is typically from the warm boundary layer on the front side, $28 \%$ entrained via perforations and $10 \%$ from the back surface of collector. Porosity, plenum dimensions, plenum air velocity, wind, velocity and collector absorptance determine the performance of transpired solar collectors.

By producing both electrical and thermal energy use of either (i) co-located separate solar thermal collectors and PV panels or (ii) a hybrid photovoltaic-thermal (PV/T) system eliminates the dependency on grid/or battery storage to operate air circulating fans. photovoltaic/thermal air (PV/T air) collectors have included both single and double pass air heaters (Bhargava et al., 1991; Hegazy, 2000; Sopian et al., 2000; Sandnes and Rekstad, 2002). Hegazy (2000) in an investigation of four different type of photovoltaic (PV)/thermal solar air collector configurations found that the overall electrical and thermal efficiency can increase by $55 \%$ at $0.04 \mathrm{~kg}$ / $\mathrm{m}^{2} \mathrm{~s}$ mass flow rate of air when flow through between the top glass cover and a solar cell. Zakharchenko et al. (2004) analysed silicon cells integrated onto a black plastic solar heat absorber in an (unglazed PV/T system. The integration of a reflector in a PV/T system can enhance both electrical and thermal output (Tripanagnostopoulos et al., 2002; Coventry, 2005). For a double pass PV/T solar collector with a compound parabolic concentrator, installation of fins on the rear side increased heat transfer between photovoltaic panel and air (Othman et al., 2005, 2007). Various dryer designs have used solar thermal collectors have been equipped with reflectors to concentrate solar energy (Akyurt and Selcuk, 1973; Chew et al., 1989; Hodali and Bougard, 2001; Madhlopa and Ngwalo, 2007; Tiwari et al., 1994; Shams et al., 2016).

\section{Solar dryer configurations}

\subsection{Solar drying taxonomy}

The taxonomy of drying using solar energy is given in Fig. 7.
To fully model a solar drying process requires detailed examination of solar radiative heat transfer, dehydration of porous foodstuffs, fluid dynamics and modelling the chemical changes in dietary properties. It has been noted that multi-objective process optimization requires, as a minimum, the development of more complete multiphysics models (Defraeye, 2014).

\subsection{Open sun drying}

In open sun drying as shown in Fig. 8 the portion of solar energy absorbed at the crop surface increases the crop temperature resulting in

(i) emission of long wavelength thermal radiation

(ii) convective heat loss

(iii) mass transfer of moisture from the surface of the crop to ambient air of drying which depends upon the rate of this diffusion process by which moisture moves to the surface depending upon product type (Sodha et al., 1985, 1987).

The main disadvantages of open sun drying is crop loss due to (i) consumption by rodents, birds, insects, and micro-organisms, (ii) unexpected rain or storms, (iii) excessive or insufficient drying, (iv) contamination due to dust, dirt, insects, and micro-organisms, (v) colour loss due to UV exposure, (vi) large area required, (vii) readsorption of moisture during off sunshine hours, and (viii) it often produces products of insufficient quality to be marketable in domestic and international markets (Esper and Muhlbauer, 1998; Koyuncu, 2006; Lutz et al., 1987; Mustayen et al., 2014; Oztekin et al., 1999; Sodha et al., 1985; Sodha and Chandra, 1994). Open sun drying of agricultural and other products may have commenced as an artificial continuation of an in-situ drying. A large portion of the world's supply of dried fruits and vegetables continues to be sun dried in the open without technical aids (Szulmayer, 1971).

\subsection{Direct passive solar dryers}

When solar energy collection forms a integral part of the roof/ wall of the drying chamber forms a direct dryer as shown in Fig. 9.

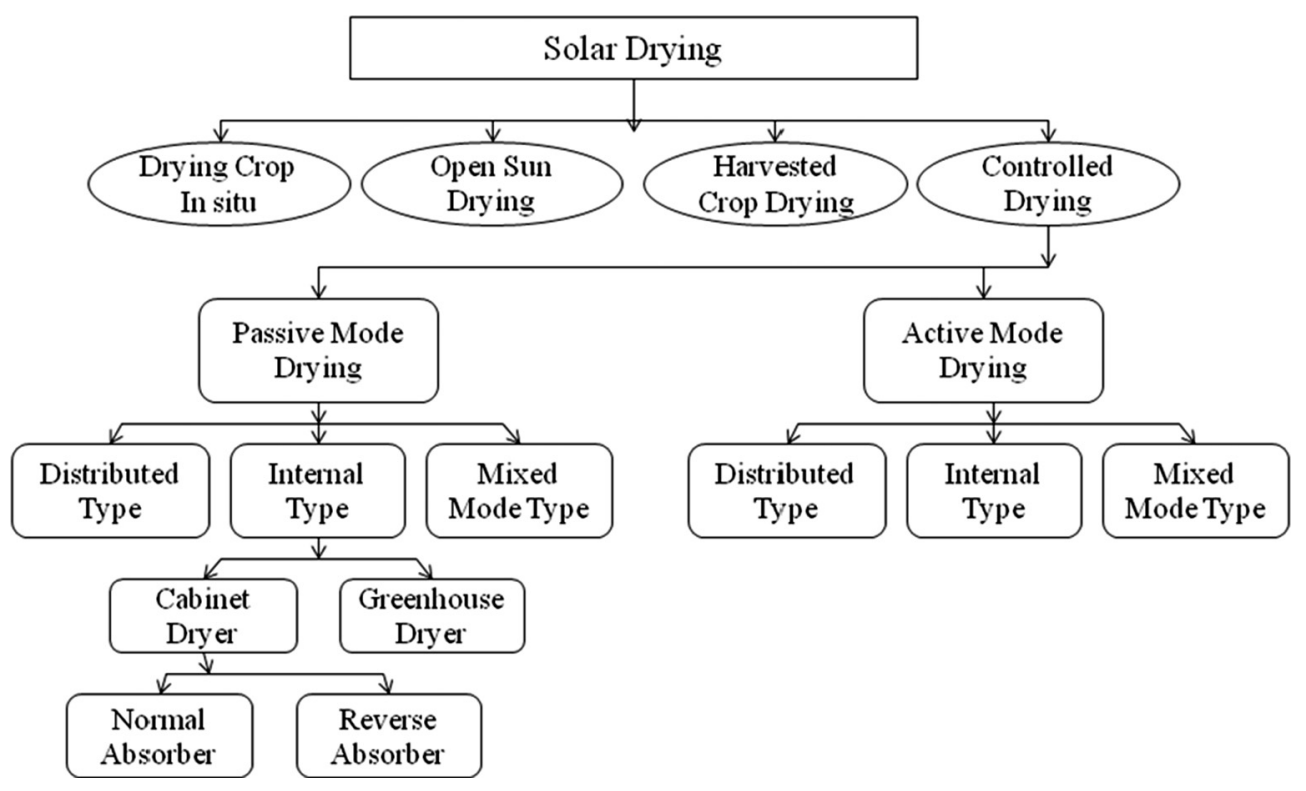

Fig. 7. Solar drying taxonomy. 


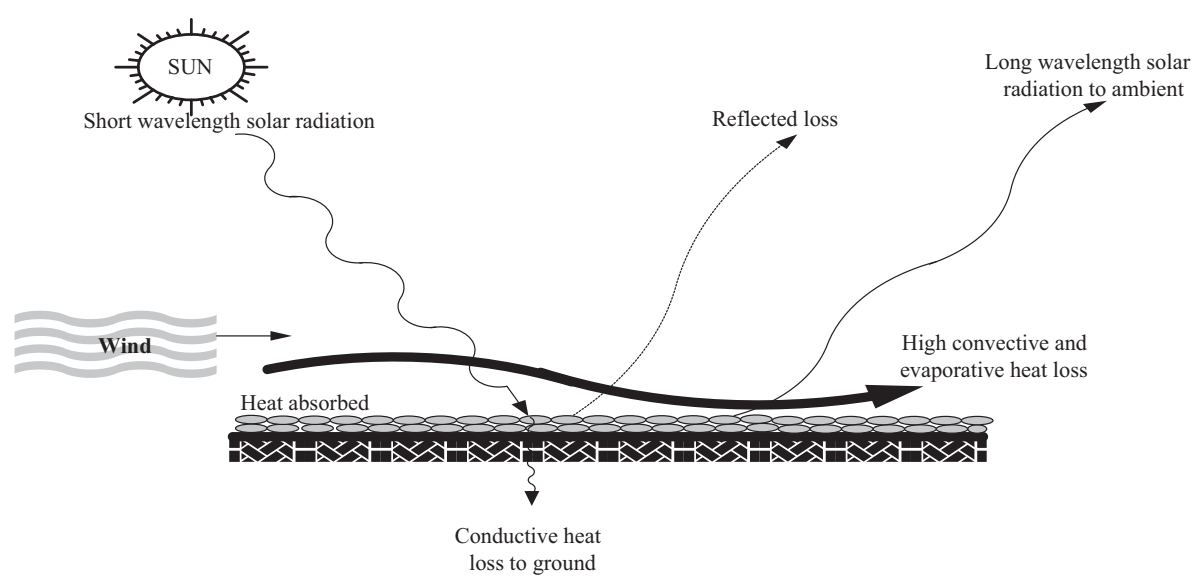

Fig. 8. Open sun drying.

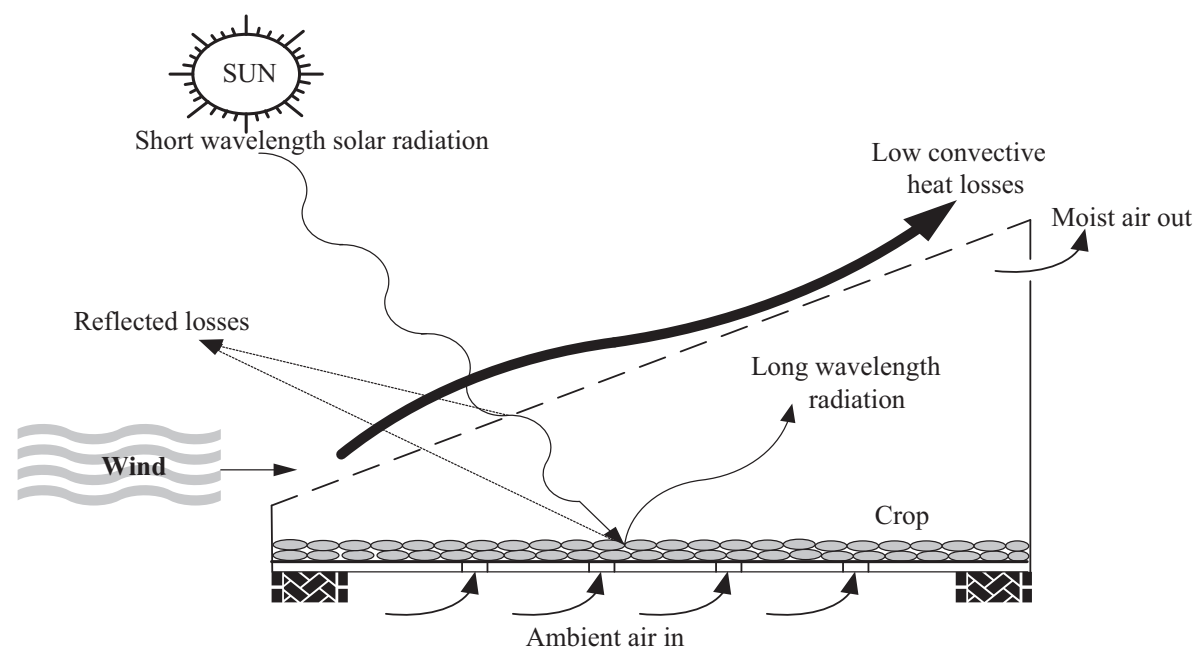

Fig. 9. Schematic diagram of direct solar drying.

In a direct passive solar dryer, solar radiation is directly incident on a crop placed in a transparent wall-drying chamber. The relative humidity of the resident air decreases to carry moisture. Natural air circulation removes the moisture removed by natural air circulation (Ekechukwu and Norton, 1999a, 1999b; Onyegegbu et al., 1994).

Solar cabinet dryers, probably the first types of solar dryer to be studied scientifically (Lawand, 1965, 1966, 1977; Kapoor and Agrawal, 1973), have been used in many climates to dry a wide variety of crops (Datta et al., 1988; Sharma et al., 1990; Thanvi and Pande, 1987). Intended for domestic use a solar cabinet dryer consists of a box insulated at both its base and sides, with a single or double-glazed roof. Holes at its base and at upper parts of the sides allow buoyancy driven moisture removal (Tiwari and Ghosal, 2005; Chua and Chou, 2003). That can be enhanced by the addition of a chimney (Ghaffari and Mehdipour, 2015). Adequate moisture removal is essential both for the drying process and to prevent insolation transmission being reduced by moisture condensating inside the glass cover.

A cabinet type dryer can dry a crop more rapidly than to opensun drying (Esper and Muhlbauer, 1998; Sodha et al., 1985) Cabinet dryers are perfectly suitable for drying small batches of fruits and vegetables such as banana, pineapple, mango, potato, carrots, and French beans (Jayaraman et al., 2000). In a cabinet dryer solar energy ultraviolet exposure can discolour a crop, use of photo selective acrylic operture materials can reduce both loss of colour and anti oxidant content. This has been demonstrated for the drying of apricots (Milczarek et al., 2016). Insolation transmission can be reduced due moisture condensation inside glass cover. In a reverse absorber cabinet dryer, the absorber plate is downward facing with reflected solar radiation incident on it from below (Goel et al., 1987; Goyal and Tiwari, 1997, 1999; Jain, 2007; Tiwari, 1986). In this dryer, the crop is not exposed directly to solar radiation to which lessens discolouration and surface cracking of the crop. Convective heat loss from the absorber is suppressed due to it being downward-facing.

Vents sized and placed to adjust the airflow gives control over the drying process in large scale, properly designed greenhouse dryers when compared to cabinet dryers (Anon., 1980). Greenhouse dryers are recommended for drying many different agricultural products (Bala and Hossain, 1998; Charters et al., 1989; Dajokoto et al., 1989; Ekechukwu and Norton, 1997; Fuller et al., 1994; Hossain and Bala, 2007; Hossain et al., 2005; Jain and Tiwari, 2004a, 2004b, 2003; Lutz et al., 1987; Lutz and Muhlbauer, 1986; Muthuveerappan et al., 1978, 1985; Shaw, 1981; Sodydov and Khairiddinov, 1982; Brenndorfer et al., 1985; El-Sebaii et al., 2002; Sallam et al., 2015; Sodha et al., 1987; Brenndorfer et al., 1985; Cura and Trim, 1982; Doe and Ahmed, 
1977; Doe, 1977, 1979). A greenhouse solar dryers can also employ a chimney that maybe augmented with a blackened internal absorber to achieve faster moisture removal (Ekechukwu and Norton, 1997, 1998, 1999a, 1999b).

\subsection{Indirect passive solar dryers}

When a solar collector is separated from drying chamber it forms an indirect solar dryer as shown in Fig. 10. Mixed -mode type dryers combine features of direct and indirect dryers (Ekechukwu and Norton, 1999a; Mustayen et al., 2014; Tiwari and Ghosal, 2005).

In an indirect solar dryer, an opaque drying chamber contains a crop placed on trays. The drying chamber is heated by circulating air warmed by a low pressure-drop air-heating solar collector.

Since solar radiation does not directly incident on the crop, caramelisation and localized heat damage do not usually occur. These dryers are suitable for retaining (i) vitamins in preserved fruits, and (ii) colour in highly pigmented commodities. The separate air heater and drying chambers (Jain and Tiwari, 2015; Jain, 2007; Pangavhane et al., 2002; Pangavhane and Sawhney, 2002) are usually connected by a flexible insulated conduct. A door provides loading access to north side of the drying chamber. The air collector can be inclined to receive maximum solar radiation for the particular time of year when dried crop is harvested. A wide variety of phase change and sensible thermal energy storage has been employed with solar dryers (Kant et al., 2016; El Khadraoui et al., 2017b) with a particular emphasis on the use of rock beds (Jain and Jain, 2004; Sharma et al., 1991; Tiwari et al., 1994; Madhlopa and Ngwalo, 2007, and water. Many autonomous solar dryers have no auxiliary heating as thermal mass provides shortterm heat storage to enable drying to continue in intermittently, cloudy or inclement weather (Condori et al., 2017 Ayua et al., in press). Crops that dry rapidly are suited to such dryers as thermal mass is rarely sufficient to sustain drying nocturnally (Sekyere et al., 2016).

A typical mixed-mode natural circulation solar-energy dryers is similar to indirect mode dryer but incorporates glazed surfaces to the drying chamber (Archuleta et al., 1983; Ayensu and AsieduBondzie, 1986; El-Sebaii et al., 2002; Exell et al., 1979; Mustayen et al., 2014; Ong, 1979; Roberto, 1984; Sharma et al., 1986; Simate, 2003; Eissen and Miihlbauer, 1983; Ayensu and AsieduBondzie, 1986).

\subsection{Active forced-circulation solar energy dryers}

Active solar energy dryers use fans to circulate heated air from the solar collector to the drying chamber. For higher moisture content crops such as papaya, kiwi fruits, brinjal, cabbage and cauliflower slices, active solar dryers have often found to be more suitable than passive solar dryers (Taylor and Weir, 1985; Chua and Chou, 2003). Forced-convective greenhouse dryers are used for large-scale commercial applications (Huang and Bowers, 1977; Huang and Toksoy, 1981, 1983; Huang, 1980; Ozisik et al., 1980; Müller et al., 1989; Taylor and Weir, 1985). There is a large diversity of forms from large-scale transparent roof "solar barns" (Shove et al., 1981) to small-scale forced-convection dryers (Bailey and Williamson, 1965; Bassey, 1985; Umarav and Ikramov, 1978). For a active indirect solar dryer the components, are a drying chamber, air heating solar collector, fan and connecting ducts (Garg et al., 1994; Ong, 1982, 1999; Roa and Macedo, 1976; Sharma et al., 1993; Tiris et al., 1994; Eissen and Miihlbauer, 1983; Fohr and Arnaud, 1992; Akachukwu, 1986; Plumptre, 1979; Calderwood, 1981; Pattanayak et al., 1978; Reddy et al., 1979; Smith, 1977; Trim and Ko, 1982; Bolin et al., 1978; Calderwood, 1981; Miller, 1985; Tiris et al., 1995; Tschernitz and Simpson, 1979). By controlling air-flow rates, active indirect solar dryers can achieve efficient drying with good final product quality particularly where real-time monitoring of crop moisture content is used for process control. In small-scale indirect solar dryers, the effect of airflow rate on the maximum evaporation rate depends on the ratio of the total drying area to the crosssectional area of the drying chamber (Blanco-Cano et al., 2016b). To achieve acceptable evaporation notes for typical units and operating conditions, this ratio is recommended in between 200 and 300 .

\subsection{Mixed mode active solar dryers}

Inactive mixed mode solar dryers (Akyurt and Selcuk, 1973; El Khadraoui et al., 2017a; Selçuk et al., 1974; Simate, 2003; Lutz et al., 1987; Mabrouk and Belghith, 1994; Mastekbayeva et al., 1998). Forced circulation of heated air from an air-heating solar collector to the glazed drying chamber is accomplished by fans operated either by AC electricity obtained fromas grid or DC electricity produced by photovoltaic (PV) modules (Jain and Tiwari, 2004a, 2004b; Mumba, 1995a, 1995b, 1996; Tsamparlis, 1990;

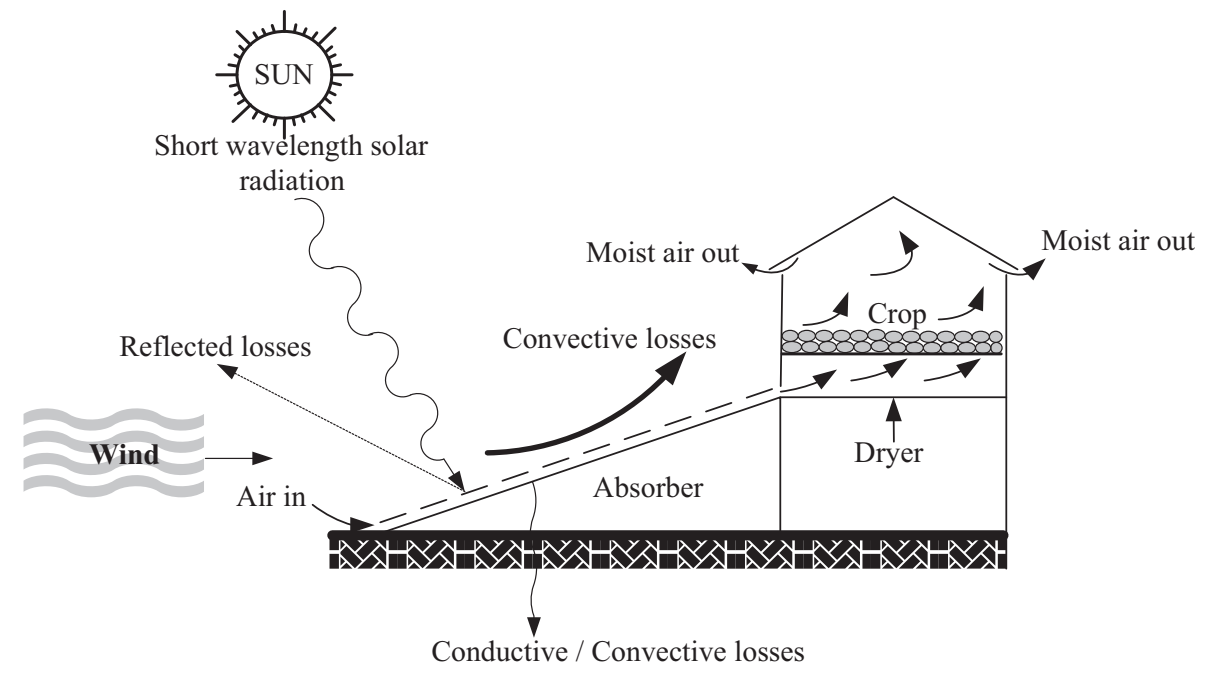

Fig. 10. Indirect solar drying. 
Farkas et al., 1999; Huang et al., 2001; Saleh and Sarkar, 2002). PV powered fans have been integrated into tunnel type and greenhouse type hybrid mixed mode dryers (Bala et al., 2003; Hossain and Bala, 2007; Hossain et al., 2005; Barnwal and Tiwari, 2008).

A solar collector can form the roof and/or wall of a drying chamber (Ong, 1979; Bowrey et al., 1980; Kocher et al., 1981; Muthuveerappan et al., 1985; Bala and Janjai, 2007) or an agricultural building for which a batch dryer located inside the building (Chua and Chou, 2003; Imre and Palaniappan, 1996; Imre, 1995). Such active solar dryers have been used for drying of higher moisture content foodstuffs such as papaya, kiwi fruits, brinjal, cabbage and cauliflower slices. In solar collector-wall dryer (Kocher et al., 1981), a black-painted and glazed concrete wall forms the solar collector whilst also serving as thermal storage (Ivanova and Andonov, 2001; Ivanova et al., 2003).

Hybrid solar dryers have used biomass for auxiliary heating to prolong drying continually into the night. Such dryers have used for nuts such as cashews (Dhanushkodi et al., in press). Biomass fuels have also been dried in solar tunnel dryers (Subhana and Natarajan, 2016). A mathematical model has been developed for drying mushrooms that includes shrinkage (Rahman et al., 2016). A solar-assisted heat pump dryer has been used to dry cassava (Yahya et al., 2016) and when combined with heat recovering and thermal storage, was found to be particularly suitable for mushroom drying (Qui et al., 2016). Too rapid drying of nuts can lead to core hardening with poor interior drying recirculation of the solar drying air is thus employed to give a drying rate that provides acceptable product quality whilst making efficient use of the heated air. This technique has been applied successfully to the drying of pistachio kernals (Mokhtarian et al., 2016).

\section{Conclusion}

For many crops, particular combinations of crop prepreparation, solar drying equipment and process management are now in use successfully to dry crops in applicable seasonal weather conditions. In other instances, promising research has not been applied to-date to significantly reduce crop-processing losses. More research is required to determine how solar drying could be readily incorporated into existing part-harvest processing chains thereby reducing barriers to appropriate adoption. As has been shown, solar crop drying brings together the complexities of internal crop structures, human nutrition, food aesthetics and process of crop decay with those of solar dryer design and process control under varying solar radiation intensities. It is probably unnecessary to have a theoretical framework that deals in all details of such a complex system in all circumstances. However research that draws together generic crop, dryer and climate combinations would enable more systematic future development of solar drying. The lack of clear benchmarks for performance intercomparison impedes the ability of new research to build constructively on previous work.

\section{References}

Akachukwu, A.E., 1986. Solar kiln dryers for timber and agricultural crops. Int. J. Ambient Energy 7 (2), 95-101.

Akyurt, M., Selcuk, M.K., 1973. A solar drier supplemented with auxiliary heating systems for continuous operation. Sol. Energy 14, 313-320.

Alam, A., Singh, G., 2004. Status and Future Needs of Farms Mechanization and Agro-processing in India. Central Institute of Agricultural Engineering, Bhopal, India.

Alam, A., Yadav, D.S., Gupta, S.K., 1980. Solar blower for grain drying and ventilation. In: Proc. ISES Congress, New Delhi, India. Pergamon Press, Oxford, pp. 20712074.

Anon., 1980. Brace Research Institute, type of solar agricultural dryers. Sunworld 4 (6), 181-188
Anon., 2004. The State of Food Insecurity in the World, Food and Agriculture Organization of the United Nations Viale delleTterme di Caracalla, 00100 Rome, Italy.

Arata, A., Sharma, V.K., Spagna, G., 1993. Performance evaluation of solar assisted dryer for low temperature drying applications - II experimental results. Energy Convers. Manage. 34 (5), 417-426.

Archuleta, R., Berkey, J., Williams, B., 1983. Research on solar food drying at the University of California, Santa Cruz. Progress in Passive Solar-energy Systems. Amer Solar Energy Soc Inc., pp. 679-683.

Ayensu, A., Asiedu-Bondzie, V., 1986. Solar drying with convective self-flow and energy storage. Sol. Wind Technol. 3 (4), 273-279.

Ayua, E., Mugalavai, V., Simon, J., Weller, S., Obura, P., Nyabinda, N., 2017. Comparison of a mixed mode of solar dryer to a direct mode solar dryer for African indigenous vegetable and chilli processing. J. Food Process. Preservat. (in press).

Bailey, P.H., Williamson, W.F., 1965. Some experiments on drying grain by solar radiation. J. Agric. Eng. Res. 10, 191-196.

Bala, B.K., Janjai, S., 2007. Solar drying technology: developments and potentials. In: Proceedings of 3rd International Conference on Solar Radiation and Day Lighting: (SOLARIS 2007), Feb. 7-9. Anamaya Publishers, New Delhi, India, pp. 298-319.

Bala, B.K., Hossain, M.D., 1998. Experimental investigation of solar drying of fish drying using tunnel dryer. In: Proc. World Renewable Energy Congress V. Pergamon Press, Italy, pp. 2049-2052.

Bala, B.K., Mondol, M.R.A., Biswas, B.K., Chowdury, B.L.D., Janjai, S., 2003. Solar drying of pineapple using solar tunnel drier. Renew. Energy 28 (2), 183-190.

Bala, B.K., 2003. Drying and Storage of Cereal Grains. Oxford \& IBH Publishing Co., Pvt. Ltd., New Delhi.

Barnwal, P., Tiwari, A., 2008. Design, construction and testing of hybrid photovoltaic integrated greenhouse dryer. Int. J. Agric. Res. 3 (2), 110-120.

Bassey, M.W., 1985. Design and performance of hybrid crop dryer using solar energy and sawdust. In: Proc ISES Cong INTERSOL 85. Pergamon Press, Montreal, Canada, pp. 1039-1042.

Blanco-Cano, L., Soria-Verdugo, A., Garcia-Gutierez, L.M., Ruiz-Rivas, U., 2016b. Explanation of the maximum evaporation rate in small indirect solar dryers. ASME J. Sol. Energy Eng. 138, 024JOR.

Bhargava, A.K., Garg, H.P., Agarwal, R.K., 1991. Study of a hybrid solar system--solar air heater combined with solar cells. Energy Conserv. Manage. 31 (5), 471-479.

Blanco-Cano, L., Soria-Verdugo, A., Garcia-Gutierrez, L.M., Ruiz-Rivas, U., 2016 a. Modelling the thin layer drying process of granny smith apples; application in an indirect solar dryer. Appl. Therm. Eng. 108, 1086-1094.

Bolin, H.R., Stafford, A.E., Huxsoll, C.C., 1978. Solar heated fruit dehydrator. Sol. Energy 20 (3), 289-291.

Bovand, M., Rashidi, S., Esfahani, J.A., 2016. Heat transfer enhancement and pressure drop penalty in porous solar heaters: numerical simulations. Sol. Energy 123, 145-159.

Bowrey, R.G., Buckle, K.A., Hamey, I., Pavenayotin, P., 1980. Use of solar energy for banana drying. Food Technol. Aust. 32 (6), 290-291.

Brennan, J.G., 1994. Food Dehydration: A Dictionary and Guide. ButterworthHeinemann Series in Food Control, Oxford, UK.

Brenndorfer, B., Kennedy, L., Bateman, C.O., Trim, D.S., Mrema, G.C., Wereko-Brobby, C., 1985. Solar Dryers - Their Role in Post Harvest Processing, Commonwealth Science Council. Commonwealth Secretariat Publications, London, UK.

Brooker, D.B., Bakker-Arkema, F.W., Hall, C.W., 1974. Drying Cereal Grains. AVI Publishing Company, Inc., Westport, USA.

Brunauer, S., Emmett, P.H., Teller, E., 1938. Adsorption of gases in multimolecular layers. J. Am. Chem. Soc. 60, 309-320.

Budin, R., Mihelić-Bogdanić, A., 1994. Application of solar energy in drying processes. Energy Convers. Manage. 35 (2), 97-103.

Calderwood, D.L., 1981. Solar Assisted Rice Drying in a Continuous-flow Dryer. ASAE Technical, pp. 81-3549.

Caouris, Y., Rigopoulos, R., Tripanagnostopoulos, J., Yianoulis, P., 1978. A novel solar collector. Sol. Energy 21 (2), 157-160.

Charters, W.W.S., Macdonald, R.W.G., Kaye, D.R., Sun, X., 1989. Passive greenhouse type solar dryer and their development, RERIC. Int. Energy J. 11 (2), 51-60.

Chen, C.C., Morey, R.V., 1989. Comparison of four EMC/ERH equations. Trans. ASAE 32 (3), 983-990.

Chen, C.S., Clayton, J.T., 1971. The effect of temperature on sorption isotherm of biological materials. Trans. ASAE 14 (5), 927-929.

Chew, T.C., Tay, A.O., Wijeysundera, N.E., 1989. A numerical study of natural convection in CPC solar collectors with tubular absorbers. Trans. ASME J. Sol. Energy Eng. 111, 16-23.

Chua, K.J., Chou, S.K., 2003. Low cost drying methods for developing countries. Trends Food Sci. Technol. 14, 519-528.

Condori, M., Duran, G., Echazu, R., Altobelli, F., 2017. Semi-industrial drying of vegetables using an array of large solar air collectors. Energy Sustain. Dev. 37, $1-9$.

Coventry, J.S., 2005. Performance of a concentrating photovoltaic/thermal solar collector. Sol. Energy 78 (2), 211-222.

Cura, C.A., Trim, D.S., 1982. Comparative study of three solar fish dryers. In: Proc FAO Expert Consultation on Fish Tech in Africa. Casablanca, Morocco, pp. 8332199.

Dajokoto, I.K., Maurere, R., Muhlbauer, W., 1989. A solar tunnel dryer for drying paddy. AMA 20 (3), 41-43.

Datta, G., Garg, H.P., Ray, R.A., Prakash, J., 1988. Performance prediction of cabinet type solar drier. Sol. Wind Technol. 5 (3), 289-292. 
Day, D.L., Nelson, G.L., 1965. Desorption isotherms for wheat. Trans. ASAE 8, 293 297.

DeLong, D., 1992. How to Dry Foods. HP Books, Los Angeles, CA.

Defraeye, T., 2014. Advanced computational modelling for drying processes - a review. Appl. Energy 131, 323-344.

Dhanushkodi, S., Wilson, V.H., Sudhalear, K., in press. Mathematical Modelling of Drying Behaviour of Cashew in a Solar Biomass Hybrid Dryer. Resource-Efficient Technologies (in press).

Diamante, L.M., Munro, P.A., 1991. Mathematical modelling of hot air drying of sweet potato slices. Int. J. Food Sci. Technol. 26, 99.

Diamante, L.M., Munro, P.A., 1993. Mathematical modeling of the thin layer solar drying of sweet potato slices. Sol. Energy 51 (4), 271-276.

Doe, P.E., Ahmed, M., Muslemuddin, M., Sachithananthan, K.A., 1977. A polythene tent dryer for improved sun drying of fish. Food Tech. Aust. 29, 437-441.

Doe, P.E., 1977. Sun powered fish drying. Aust. Fish 36 (5), 24-25.

Doe, P.E., 1979. The polyethylene tent fish dryer: a progress report. In: Energy, Waste \& Processing-Proc Int Conf Agric Engng in National Dev, Selangor, Malaysia, vol. 79, no. 12 , pp. 250-254.

Doymaz, I., 2007. The kinetics of forced convective air-drying of pumpkin slices. J. Food Eng. 79 (1), 243-248.

Duffie, J.A., Beckman, W.A., 2013. Solar Engineering of Thermal Processes. J. Wiley and Sons, New York, USA.

Eissen, W., Miihlbauer, W., 1983. Development of low-cost solar grape dryers. In: Proc. Int. Workshop Solar Drying and Rural Development, Leptensam Laboratoire Energetique et Phenomenes de Transfert, Bordeaux, pp. 263-272.

Ekechukwu, O.V., Norton, B., 1998. Effects of seasonal weather variations on the measured performance of a natural-circulation solar-energy tropical crop dryer. Energy Convers. Manage. 39 (12), 1265-1276.

Ekechukwu, O.V., Norton, B., 1997. Experimental studies of integral-type naturalcirculation solar-energy tropical crop dryers. Energy Convers. Manage. 38 (14), 1483-1500.

Ekechukwu, O.V., Norton, B., 1999a. Review of solar-energy drying systems II: an overview of solar drying technology. Energy Convers. Manage. 40 (6), 615-655.

Ekechukwu, O.V., 1999. Review of solar-energy drying systems I: an overview of drying principles and theory. Energy Convers. Manage. 40, 593-613.

Ekechukwu, O.V., Norton, B., 1999b. Review of solar-energy drying systems III: low temperature air-heating solar collectors for crop drying applications. Energy Convers. Manage. 40 (6), 657-667.

El Khadraoui, A., Kooli, S., Hamdi, I., Farhat, A., 2017a. Experimental investigation and economic evaluation of a new mixed mode solar greenhouse dryer for drying of red pepper and grape. Renew. Energy 77, 1-8.

El-Sebaii, A.A., Aboul-Enein, S., Ramadan, M.R.I., El-Gohary, H.G., 2002. Empirical correlations for drying kinetics of some fruits and vegetables. Energy 27 (9), 845-859.

Esper, A., Muhlbauer, W., 1998. Solar drying - an effective means of food preservation. Renew. Energy 15, 95-100.

Exell, R.H.B., Kornsakoo, S., Thiratrakoolchai, S., 1979. A low cost solar rice dryer for farmers in South-East Asia. Agric. Mechan. Asia, 75-78.

Farkas, I., Seres, I., Mészáros, C.S., 1999. Analytical and experimental study of a modular solar dryer. Renew. Energy 16 (14), 773-778.

Farkas, I., 2003. Control aspects of postharvest technologies. In: Chakraverty, A. Mujumdar, A.S., Raghavan, G'.S.V., Ramaswamy, H.S. (Eds.), Handbook of Postharvest Technology: Cereals, Fruits, Vegetables, Tea, and Spices. Marcel Dekker Inc., New York-Basel, pp. 845-866.

Flores, N.C., 2007. Drying Foods. Guide E-322. Las Cruces, New Mexico, USA.

Fohr, J.P., Arnaud, G., 1992. Grape drying: from sample behavior to the drier project. Drying Technol. 10 (2), 445-465.

Fudholi, A., Sopian, K., Alghoul, M.A., Ruslan, M.H., Othman, M.Y., 2015. Performances and improvement potential of solar drying system for palm oil fronds. Renew. Energy 78, 561-565.

Fuller, R.J., Mollah, M.R., Hayes, R.J., 1994. A rotary tray system for a solar fruit drier. Agric. Mechanizat. Asia Africa Latin Am. 25 (4), 45-48.

Ghaffari, A., Mehdipour, R., 2015. Modeling and improving the performance of cabinet solar dryer using computational fluid dynamics. Int. J. Food Eng. 11 (2), 157-172.

Garg, H.P., Mahajan, R.B., Sharma, V.K., Acharya, H.S., 1994. Design and development of a simple solar dehydrator for crop drying. Energy Convers. Manage. 24 (3), 229-235.

Goel, V.K., Chandra, R., Raychaudhuri, B.C., 1987. A study on the performance of a two-absorber reverse flat-plate collector. Energy Convers. Manage. 27 (4), 335 3418.

Goyal, R.K., Tiwari, G.N., 1997. Parametric study of a reverse flat plate absorber cabinet dryer: a new concept. Sol. Energy 60 (1), 41-48.

Goyal, R.K., Tiwari, G.N., 1999. Performance of a reverse flat plate absorber cabinet dryer: a new concept. Energy Convers. Manage. 40 (4), 385-392.

Gunhan, T., Demir, V., Hancioglu, E., Hepbasli, A., 2005. Mathematical modelling of drying of bay leaves. Energy Convers. Manage. 46 (11-12), 667-1679.

Hall, C.W., 1980. Drying and Storage of Agricultural Crops. AVI, West port, USA.

Hegazy, A.A., 2000. Comparative study of the performance of four photovoltaic thermal solar air collectors. Energy Convers. Manage. 41 (8), 861-881.

Henderson, S.M., 1952. A basic concept of equilibrium moisture. Agric. Eng. 33 (1), 29-32.

Hodali, R., Bougard, J., 2001. Integration of a desiccant unit in crops solar drying installation: optimization by numerical simulation. Energy Convers. Manage. 42 (13), 1543-1558.
Hollands, K.G.T., 1963. Directional selectivity, emittance and absorptance properties of veer corrugated specular surfaces. Sol. Energy 7 (3), 108-116.

Hollick, J., 1998. Solar cogeneration panels. Renew. Energy 15, 195-200.

Hollick, J., 1994. Unglazed solar wall air heaters. Renew. Energy 5, 415-421.

Hossain, M.A., Bala, B.K., 2007. Drying of hot chilli using solar tunnel drier. Sol. Energy 81 (1), 85-92.

Hossain, M.A., Woods, J.L., Bala, B.K., 2005. Optimisation of solar tunnel drier for drying of chilli without color loss. Renew. Energy 30 (5), 729-742.

Huang, B.J., Lin, T.H., Hung, W.C., Sun, F.S., 2001. Performance evaluation of solar photovoltaic/thermal systems. Sol. Energy 70 (5), 443-448.

Huang, B.K., Bowers, C.G., 1977. Solar-energy utilization using greenhouse bulk curing and drying systems. In: Proc Solar Crop Drying Conf. Raleigh, USA, pp. 117-145.

Huang, B.K., Toksoy, M., 1983. Design and analysis of greenhouse solar systems in agricultural production. Energy Agric. 2, 115-136.

Huang, B.K., Toksoy, M., 1981. Greenhouse solar system for effective year-round solar-energy utilization in agricultural production. Agric. Energy 1, 152.

Huang, B.K., 1980. Effective solar-energy utilization in tobacco production with greenhouse bulk curing solar barn. In: Inf Bull 7th Int Tobacco Sci Congr Manila. Philippines, p. 14.

Iglesias, H.A., Chirife, J., Viollaz, P., 1976. Thermodynamics of water vapour sorption by sugar beet root. J. Food Eng. 11, 91-101.

Imre, L., Palaniappan, C., 1996. Development of solar drying. Drying Technol. 14 (6), 1381-1388.

Imre, L., 1995. Solar drying. In: Mujumdar, A.S. (Ed.), Handbook of Industrial Drying New York. Marcel Dekker, pp. 373-452.

Imre, L., 1993. Energy aspects of drying. In: Palaniappan, C., Kumar, S., Haridasan, T. M. (Eds.), Proc. Energy Perspectives in Plantation Industry. Interline, Bangalore, India, pp. 122-133.

Ivanova, D., Andonov, K., 2001. Analytical and experimental study of combined fruit and vegetable dryer. Energy Convers. Manage. 42 (8), 975-983.

Ivanova, D., Enimanev, Kr., Andonov, K., 2003. Energy and economic effectiveness of a fruit and vegetable dryer. Energy Convers. Manage. 44 (5), 763-769.

Jain, D., Jain, R.K., 2004. Performance evaluation of an inclined multi-pass solar air heater with in-built thermal storage on deep-bed drying application. J. Food Eng. 65 (4), 497-509.

Jain, D., Tiwari, P., 2015. Performance of indirect through pass natural convective solar crop dryer with phase change thermal energy storage. Renew. Energy 80 244-250.

Jain, D., Tiwari, G.N., 2004a. Effect of greenhouse on crop drying under natural and forced convection II: thermal modeling and experimental validation. Energy Convers. Manage. 45, 2777-2793.

Jain, D., Tiwari, G.N., 2004b. Effect of greenhouse on crop drying under natural and forced convection I. Evaluation of convective mass transfer coefficient. Energy Convers. Manage. 45, 765-783.

Jain, D., Tiwari, G.N., 2003. Thermal aspects of open sun drying of various crops Energy 28, 37-54.

Jain, D., 2007. Modeling the performance of the reversed absorber with packed bed thermal storage natural convection solar crop dryer. J. Food Eng. 78 (2), $637-$ 647.

Jayaraman, K.S., Dasgupta, D.K., Baburao, N., 2000. Solar drying of vegetables. In: Mujumdar, A.S., Suvachittanont, S. (Eds.), Developments in Drying, Food Dehydration, vol. 1. Kasetsart University Press, Bangkok, pp. 179-206.

Kant, K., Shukla, A., Sharma, A., Kumar, A., Jain, A., 2016. Thermal energy storage based solar drying systems; a review. Innovat. Food Sci. Emerg. Technol. 34, 8699.

Kamiloglu, S., Toydemir, G., Boyacioglu, D., Beekwilder, J., Hall, R.D., Capanoglu, E., 2016. A review on the effect of drying on antioxidant potential of fruits and vegetables. Crit. Rev. Food Sci. Nutr. 56, 110-129.

Kapoor, S.G., Agrawal, H.C., 1973. Solar dryers for Indian conditions. In International Congress on the Sun in the Service of Mankind, Paris.

Karathanos, V.T., 1999. Determination of water content of dried fruits by drying kinetics. J. Food Eng. 39, 337-344.

Karim, M.A., Hawlader, M.N.A., 2004. Development of solar air collectors for drying applications. Energy Convers. Manage. 45 (3), 329-344.

El Khadraoui, A., Bouadila, S., Kooli, S., Farhat, A., Guizani, A., 2017b. Therma behaviour of indirect solar dryer; nocturnal usage of solar air collector with PCM. J. Clear. Prod. 148, 37-48.

Kocher, M.F., Bodman, G.R., Lay, M., 1981. Solar grain drying and farrowing house heating with a multi-use collector. Am. Soc. Agric. Eng., 81-4554

Koyuncu, T., 2006. An investigation on the performance improvement of greenhouse-type agricultural dryers. Renew. Energy 31 (7), 1055-1071.

Lahnine, L., Idlimam, A., Mahrouz, M., Mghazli, S., Hidar, N., Hanine, H., Kontit, A. 2016. Thermo-physical characterisation by solar convective drying of thyme conserved by an innovative thermal biochemical process. Renew. Energy 94 $72-80$.

Lawand, T.A., 1965. A description of two simple solar agricultural dryers. Cooper Mediterraneene pour l' Energie Solair 9, 51-56.

Lawand, T.A., 1966. A solar-cabinet dryer. Sol. Energy 10 (4), 158-164.

Lawand, T.A., 1977. The potential of solar agricultural dryers in developing areas. In: UNIDO Conf 5, Tech for Solar Energy Utilization, pp. 125-132.

Li, B., You, S., Ye, T., Zhang, H., Li, X., Li, C., 2014. Mathematical modeling an experimental verification of vacuum glazed transpired solar collector with slitlike perforations. Renew. Energy 69, 43-49.

Löf, G.O.G., 1962. Recent investigations in the use of solar energy for the drying of solids. Sol. Energy 6 (4), 122-128. 
Lorriman, D., Hollick, V., 2003. Solar crop drying: a simple alternative to fossil fuel powered drying. Refocus 1, 48-49.

Lozano, J.E., Rotstein, E., Urbicain, M.J., 1983. Shrinkage, porosity and bulk density of foodstuffs at changing moisture contents. J. Food Sci. 48, 1497-1502.

Lozano, J.E., Rotstein, E., Urbicain, M.J., 1980. Total porosity and open-pore porosity in the drying of fruits. J. Food Sci. 45, 1403-1407.

Luikov, A.V., 1996. Heat and Mass Transfer in Capillary-Porous Bodies. Pergamon Press, Oxford.

Lutz, K., Muhlbauer, W., Muller, J., Reisinger, G., 1987. Development of a multipurpose solar crop dryer for arid zones. Sol. Wind Technol. 4, 417-424.

Lutz, K., Muhlbauer, W., 1986. Solar tunnel dryer with integrated collector. Drying Technol. 4 (4), 583-603.

Mabrouk, S.B., Belghith, A., 1994. Simulation and design of a tunnel drier. Renew. Energy 5 (1-4), 469-473.

Madhlopa, A., Ngwalo, G., 2007. Solar dryer with thermal storage and biomassbackup heater. Sol. Energy 81 (4), 449-462.

Mahapatra, A.K., Imre, L., 1990. Role of solar agricultural drying in developing countries. Int. J. Ambient Energy 2, 205-210.

Mastekbayeva, G.A., Leon, M.A., Kumar, S., 1998. Performance evaluation of a solar tunnel dryer for chilli drying. Paper presented at the 'ASEAN Seminar \& Workshop on Drying Technology' held during 3-5 June, at Phitsanulok, Thailand.

Mayor, L., Sereno, A.M., 2004. Modelling shrinkage during convective drying of food materials: a review. J. Food Eng. 61, 373-386.

Mclaughlin, C.P., Magee, T.R.A., 1998. The effect of shrinkage during drying of potato spheres and the effect of drying temperature on vitamin $C$ retention. Trans. Chem. E 76 (C), 138-142.

Midilli, A., Kucuk, H., 2003. Mathematical modeling of thin layer drying of pistachio by using solar energy. Energy Convers. Manage. 44 (7), 1111-1122.

Milczarek, R.R., Avena-Mascareno, R., Alonzo, J., Fichot, M.I., 2016. Improving the sun drying of apricots (Prunus armeniaca) with photo-selective dryer cabinet materials. J. Food Sci. 81, 2466-2475.

Miller, W.M., 1985. Solar drying coupled with solid desiccant energy storage. Trans. ASAE 28 (2), 649-656.

Mokhtarian, M., Tavakolipour, H., Kalbasi-Ashtari, A., 2016. Energy and exergy analysis in solar drying of pistachio with air recycling system. Drying Technol. 34, 1484-1500.

Müller, J., Reisinger, G., Kisgeci, J., Kotta, E., Tesic, M., Mühlbauer, W., 1989 Development of a greenhouse-type solar dryer for medicinal plants and herbs Sol. Wind Technol. 6 (5), 523-530.

Muhlbauer, W., 1986. Present status of solar crop drying. Energy Agric. 5, 121-137.

Mulet, A., Garcia-Reverter, J., Bon, J., Berna, A., 2000. Effect of shape on potato and cauliflower shrinkage during drying. Drying Technol. 18 (6), 1201-1219.

Mumba, J., 1996. Design and development of a solar grain dryer incorporating photovoltaic powered air circulation. Energy Convers. Manage. 37 (5), 615-621.

Mumba, J., 1995a. Development of a photovoltaic powered forced circulation grain dryer for use in the tropics. Renew. Energy 6 (7), 855-862.

Mumba, J., 1995b. Economic analysis of a photovoltaic, forced-convection, sola grain drier. Energy 20 (9), 923-928.

Mustayen, A.G.M.B., Mekhilef, S., Saidur, R., 2014. Performance study of different solar dryers: a review. Renew. Sustain. Energy Rev. 34, 463-470.

Muthuveerappan, V.R., Ambalavanan, G., Kamraj, G., 1978. An experimental investigation and heat transfer studies on one ton per day solar paddy dryer and batch drying studies on solar paddy dryer one ton day capacity. In: ISES Congress, New Delhi, India. Pergamon Press, Oxford, pp. 1952-1957.

Muthuveerappan, V.R., Ambalavanan, G., Kuchithapatham, M., Kamraj, G., Ananthanatesan, T., 1985. Low cost plastic-section type greenhouse grain dryer. In: Proc. ISES Congress, INTERSOL 85. Pergamon Press, Oxford, pp. $1077-$ 1081.

Nabneun, S., Janjai, S., Thepa, S., Sudaprasert, K., Songprakorp, R., Bala, B.K., 2016 Experimental performance of a new design of solar dryer for drying osmotically dehydrated cherry tomatoes. Renew. Energy 94, 147-156.

Nair, K.K.V., Bongirwar, D.R., 1994. Solar dryer for agricultural products: a do-ityourself solar dryer. Indian Chem. Eng. 36 (3), 103-105.

Norton, B., 2013. Harnessing Solar Heat. Springer Verlay, Heidelberg, Germany.

Nolle, N., Argyropoulos, D., Ambacher, S., Muller, J., Biesalski, H.K., in press. Vitamin D2 Enrichment in Mushrooms by Natural or Artificial UV-light During Drying. LWT-Food Science and Technology (in press).

Nunes del Oliveira, R., Rodrigues Filho, F.A., Garcia Pabon, J.J., Koury, R.N.N., Machado, L., in press. Numerical Mode of an Inflatable Solar Collector. Drying Technology (in press).

Ochoa, M.R., Kesseler, A.G., Pirone, B.N., Marquez, C.A., De Michelis, A., 2002. Volume and area shrinkage of whole sour cherry fruits (Prunus cerasus) during dehydration. Drying Technol. 20 (1), 147-156.

Ong, K.S., 1982. Results of investigation into forced and natural convection solar air heater and crop dryers. Reg. J. Energy Heat Mass Transfer 4 (1), 29-45.

Ong, K.S., 1999. Solar dryers in the Asia-Pacific region. Renew. Energy 16 (1-4), 779-784.

Ong, K.S., 1979. Solar drying of paddy and timber. In: Proc Solar Energy Symp the Utilization of Solar Heat in Industry and Agriculture. Nice, France, pp. 339-350.

Onyegegbu, S.O., Morhenne, J., Norton, B., 1994. Second law optimization of integra type natural circulation solar energy crop dryers. Energy Convers. Manage. 35 (11), 973-983.

Othman, M.Y.H., Yatim, B., Kamaruzzaman, S.K., AbuBakar, M.N., 2005. Performance analysis of a double-pass photovoltaic/thermal (PV/T) solar collector with CPC and fins. Renew. Energy 30 (13), 2005-2017.
Othman, M.Y.H., Yatim, B., Sopian, K., AbuBakar, M.N., 2007. Performance studies on a finned double-pass photovoltaic-thermal (PV/T) solar collector. Desalination 209 (1-3), 43-49.

Ozisik, M.N., Huang, B.K., Toksoy, M., 1980. Solar grain drying. Sol. Energy 24 (4), 397-401.

Oztekin, S., Bascetincelik, A., Soysal, Y., 1999. Crop drying programme in Turkey. Renew. Energy 16 (1-4), 789-794.

Pangavhane, D.R., Sawhney, R.L., Sarsavadia, P.N., 2002. Design, development, and performance testing of a new natural convection solar dryer. Energy 27, 579_ 590

Pangavhane, D.R., Sawhney, R.L., 2002. Review of research and development work on solar dryers for grape drying. Energy Convers. Manage. 43, 45-61.

Park, K.J., 1998. Diffusional model with and without shrinkage during salted fish muscle drying. Drying Technol. 16 (3-5), 889-905.

Parker, B.F., 1981. Derivation of efficiency and loss factors for solar air heaters. Sol. Energy 26 (1), 27-32.

Pattanayak, S., Sengupta, P., Raychaudhuri, B.C., 1978. Continuous solar grain dryer. In: ISES Conf New Delhi, India, pp. 1449-1452.

Pfost, H.B., Mourer, S.G., Chung, D.S., Milliken, G.A., 1976. Summarizing and reporting equilibrium moisture data for grains. ASAE, 85-3512.

Pirasteh, G., Saidur, R., Rahman, S.M.A., Rahim, N.A., 2014. A review on development of solar drying applications. Renew. Sustain. Energy Rev. 31, 133-148.

Plumptre, R.A., 1979. Simple solar heated timber dryers: design, performance, and commercial viability. Commonwealth Rev. 58 (4), 243-251.

Qui, Y., Li, M., Hassanien, R.H., Wang, Y., Luo, X., Yu, Q., 2016. Performance and operation mode analysis of a heat recovery and thermal storage solarassociated heat pump drying system. Sol. Energy 137, 225-235.

Rahman, M.M., Mekhilef, S., Saidur, R., Billah, A.G.M.M., Rahman, S.M.A., 2016. Mathematical modelling and experimental validation of solar drying of mushrooms. Int. J. Green Energy 13, 344-351.

Rahman, M.S., Perera, C.O., Chen, X.D., Driscoll, R.H., Potluri, P.L., 1996. Density, shrinkage and porosity of Calamari Mantle Meat during air drying in a cabinet dryer as a function of water content. J. Food Eng. 30, 135-145.

Rashidi, S., Esfahani, J.A., Rashidi, A., 2017. A review on the applications of porous materials in solar energy systems. Renew. Sustain. Energy Rev. 73, 1198-1210.

Ratti, C., 1994. Shrinkage during drying of foodstuffs. J. Food Eng. 23 (1), 91-105.

Reddy, T.A., Pushparaj, D., Gupta, G.L., 1979. A design procedure for convective solar dryers. In: Solar Energy Symp, The Utilization of Solar Heat in Industry and Agric. Nice, France, pp. 101-111.

Roa, G., Macedo, I.C., 1976. Grain drying in stationary bins with solar heated air. Sol. Energy 18 (5), 445-449.

Roberto, R.L., 1984. Solar drying in northern Chile. Sol. Wind Technol. 1 (1), 49-58.

Saleh, T., Sarkar, M.A.R., 2002. Performance study of A PV operated. Forced convection solar energy dryer. In: A Paper Accepted for Presentation at the Technical Session of the 8th International Symposium for Renewable Energy Education (ISREE-8), Orlando, University of Florida, USA.

Sallam, Y.I., Aly, M.H., Nassar, A.F., Mohamed, E.A., 2015. Solar drying of whole mint plant under natural and forced convection. J. Adv. Res. 6, 171-178.

Sandnes, B., Rekstad, J, 2002. A photovoltaic/thermal (PV/T) collector with a polymer absorber plate: experimental study and analytic model. Sol. Energy 72 (1), 63-73.

Satcunanathan, S., Deonarine, S., 1973. A two pass solar air-heater. Sol. Energy 15 (1), 41-49.

Sekyere, C.K.K., Forson, F.K., Adam, F.W., 2016. Experimental investigation of the drying characteristics of a mixed mode natural circulation solar crops dryer with back up heater. Renew. Energy 92, 532-542.

Selcuk, M.K., 1977. Solar air heaters and their applications. In: Sayigh, A.A.M. (Ed.), Solar Energy Engineering. Academic Press, New York (Chapter 8).

Selçuk, M.K., Ersay, Ö., Akyurt, M., 1974. Development, theoretical analysis and performance evaluation of shelf type solar driers. Sol. Energy 16 (2), 81-88.

Shams, S.M.N., Mc Keever, M., Mc Cormack, S., Norton, B., 2016. Design and experiment of a new solar air-heating collector. Energy 100, 374-383.

Sharma, S., Sharma, V.K., Jha, R., Ray, R.A., 1990. Evaluation of the performance of a cabinet type solar dryer. Energy Convers. Manage. 30 (2), 75-80.

Sharma, V.K., Colangelo, A., Spagna, G., 1993. Experimental performance of an indirect type solar fruit and vegetable dryer. Energy Convers. Manage. 34 (4), 293-308.

Sharma, V.K., Rizzi, G., Garg, H.P., 1991. Design and development of an augmented integrated solar collector with rock storage system for heating applications. Energy Convers. Manage. 31 (4), 369-377.

Sharma, V.K., Sharma, S., Ray, R.A., Garg, H.P., 1986. Design and performance studies of a solar dryer suitable for rural applications. Energy Convers. Manage. 26 (1), 111-119.

Shaw, R., 1981. Solar drying potatoes. Appropr. Technol. 7 (4), 26-27.

Shove, G.C., Barton, G.W., Hall, M.D., Peterson, W.H., 1981. Field Studies of Solar Grain Drying. ASAE 81-4037.

Shukla, A., Nkwetta, D.N., Cho, Y.N., Stevenson, V., Jones, P., 2012. A state of art review on the performance of transpired solar collector. Renew. Sustain. Energy Rev, 16, 3975-3985.

Simal, S., Rosselló, C., Berna, A., Mulet, A., 1998. Drying of shrinking cylinder-shaped bodies. J. Food Eng. 37, 423-435.

Simate, I.N., 2003. Optimization of mixed-mode and indirect-mode natural convection solar dryers. Renew. Energy 28 (3), 435-453.

Smith, C.C., 1977. Solar process drying of potato products. In: ISES American Section Annual Conf. Orlando, USA, vol. 1, pp. 32-37. 
ARTICLE IN PRESS

12

V. Tolar et al./Solar Energy $x x x$ (2017) $x x x-x x x$

Sodha, M.S., Bansal, N.K., Singh, D., 1982. Analysis of a nonporous double flow solar air heater. Apple. Energy 12, 251-258.

Sodha, M.S., Bansal, N.K., Kumar, A., Bansal, P.K., Malik, M.A.S., 1987. Solar Crop Drying. CRC Press, Cleveland, Ohio.

Sodha, M.S., Chandra, R., 1994. Solar drying systems and their testing procedures: a review. Energy Convers. Manage. 35 (3), 219-267.

Sodha, M.S., Dang, A., Bansal, P.K., Sharma, S.B., 1985. An analytical and experimental study of open sun drying and a cabinet tyre drier. Energy Convers. Manage. 25, 263-271.

Sodydov, T.A., Khairiddinov, B., 1982. A year round double - block greenhouse dryer. Apple. Solar Energy 18 (1), 69-72.

Sopian, K., Lu, H.T., Kakac, S., Veziroglu, T.N., 2000. Performance of a double pass photovoltaic thermal solar collector suitable for solar drying systems. Energy Convers. Manage. 41 (4), 353-365.

Soysal, Y., Öztekin, S., 2001. Postharvest technology: comparison of seven equilibrium moisture content equations for some medicinal and aromatic plants. J. Agric. Eng. Res. 78 (1), 57-63.

Subhana, K.R., Natarajan, R., 2016. Theoretical modelling and experimental investigation of the convective drying kinetics of biomass in an improved solar tunnel dryer. Bio Fuels, 1-8.

Szulmayer, W., 1971. From sun drying to solar dehydration: I. Method and equipment. Food Technol. Australia 23, 440-443.

Taylor, U.J., Weir, A.D., 1985. Simulation of a solar timber dryer. Sol. Energy 34 (3), 249-255.

Thanvi, K.P., Pander, P.C., 1987. Development of a low cost solar agricultural dryer. Energy Agric. 6, 35-40.

Thompson, T.L., Peart, R.M., Foster, G.H., 1968. Mathematical simulation of corn drying-a new model. Trans. ASAE 24 (3), 582-586.

Tires, C., Ozbalta, N., Tiris, M., Dincer, I., 1994. Performance of a solar dryer. Energy 19 (9), 993-997.

Tiris, C., Tiris, M., Pincer, I., 1995. Investigation of the thermal efficiencies of a solar dryer. Energy Convers. Manage. 36 (3), 205-212.

Tiwari, G.N., Bhatia, P.S., Singh, A.K., Sutar, R.F., 1994. Design parameters of a shallow bed solar crop dryer with reflector. Energy Convers. Manage. 35 (6), 535-542.
Tiwari, G.N., Ghosal, M.K., 2005. Renewable Energy Resources: Basic Principles and Applications. Narosa Publishing House, New Delhi, India.

Tiwari, G.N., 1986. Simple transient analysis of a normal and reverse flat plate collector. Energy Convers. Manage. 26 (1), 145-146.

Tiwari, G.N., 2003. Solar Energy, Fundamentals, Design, Modelling and Applications. CRC Press, New York and Narosa Publishing House, New Delhi, India.

Togrul, I.T., Pehlivan, D., 2002. Mathematical modeling of solar drying of apricots in thin layers. J. Food Eng. 55, 209-216.

Trim, D.S., Ko, H.Y., 1982. Development of a forced-convection solar dryer for red peppers. Trinidad. Trope. Agric. 59 (4), 319-323.

Tripanagnostopoulos, Y., Nousia, T.H., Souliotis, M., Yianoulis, P., 2002. Hybrid photovoltaic/thermal solar system. Sol. Energy 72 (3), 217-234.

Tsamparlis, M., 1990. Solar drying for real applications. Drying Technol. 8 (2), $261-$ 285.

Tschernitz, J.L., Simpson, W.T., 1979. Solar heated forced air lumber dryer for tropical latitudes. Sol. Energy 22, 563-566.

Umarav, G.G., Ikramov, A.I., 1978. Features of the drying of fruits and grapes in solar radiation drying apparatus. Apple. Solar Energy 14 (6), 55-57.

Wang, N., Brennan, J.G., 1995. Changes in structure, density and porosity of potato during dehydration. J. Food Eng. 24 (1), 61-76.

Wijeysundera, N.E., Ah, L.L., Tjioe, L.E., 1982. Thermal performance study of two pass solar air heaters. Sol. Energy 1982 (28), 363-370.

Yahya, M., Fudholi, A., Hafizh, H., Sopian, K., 2016. Comparison of solar dryer and solar-associated heat pumps dryer for cassava. Sol. Energy 136, 606-613.

Yaldız, O., Ertekin, C., 2001. Thin layer solar drying of some different vegetables. Drying Technol. 19 (3), 583-596.

Zakharchenko, R., Licea-Jime'nez, L., Pe'rez-Garci'a, S.A., Vorobiev, P., DehesaCarrasco, U., Pe'rez-Robels, J.F., Gonza'lez-Herna'ndez, J., Vorobiev, Y., 2004. Photovoltaic solar panel for a hybrid PV/thermal system. Sol. Energy Mater. Sol. Cell 82 (1-2), 253-261.

Zaman, M.A., Bala, B.K., 1989. Thin layer solar drying of rough rice. Sol. Energy 42, $167-171$.

Zogzas, N.P., Maroulis, Z.B., Marinos-Kouris, D., 1994. Densities, shrinkage and porosity of some vegetables during air drying. Drying Technol. 12 (7), 16531666.

Please cite this article in press as: Tomar, V., et al. Solar dryers for tropical food preservation: Thermophysics of crops, systems and components. Sol.

Energy (2017), http://dx.doi.org/10.1016/j.solener.2017.05.066 